\title{
Co oznaczają nasze święta i inne specjalne dni ${ }^{1}$
}

\author{
RAFAEL ABKOWICZ
}

Janhyj. Nowy miesiąc. Pierwszy dzień każdego miesiąca. Małe święto.

Szabbat. Dzień sobotni. Siódmy dzień każdego tygodnia. Dzień odpoczynku i czytania Pisma. Tego dnia należy się powstrzymywać od jakiejkolwiek pracy. Każdy wierny zobowiązany jest poświęcić ten dzień odpoczynkowi duszy i ciała.

Chydży Tymbyłłarnyn. Pascha. Święto to jest obchodzone siedem dni. Zaczyna się wraz z zachodem słońca 14 dnia miesiąca Artarych-aj (marzeckwiecień), a kończy się wieczorem 21 dnia tegoż miesiąca. Święto to ustanowiono na pamiątkę wyjścia z niewoli egipskiej.

W ciągu tych siedmiu dni nie je się chleba wypiekanego z zakwaszonego ciasta, a jedynie placki tymbyt, które nie są z zakwaszonego ciasta. Stąd święto to nazywa się Chydży tymbyłłarnyn - świętem przaśników.

Pierwsza noc tego święta nazywa się „nocą hagady”, gdyż tej nocy czyta się Haggada, opowieść o wszelkich cudach, jakie uczynił Bóg dla ludu Izraela w Egipcie.

Pierwszy i ostatni dzień Chydży tymbyłłarnyn to dni świętej lektury. Nie wykonuje się żadnej pracy, a pożywienie na potrzeby tych dni trzeba przygotować wcześniej. Przez środkowe pięć dni święta można wykonywać pracę, jedynie modlitwy w kienesie trwają dłużej.

Od niedzieli, która wypada w czasie święta, rozpoczyna się odliczanie 50 dni do święta Chydży Aftałarnyn.

Chydży Aftałarnyn. Święto Tygodni obchodzi się na pamiątkę tego, że w Ziemi Świętej w tym czasie dojrzewało zboże, a lud udając się do Jerozolimy na obchody tego święta, przynosił ze sobą do Świątyni chleb wypieczony z mąki $\mathrm{z}$ nowego plonu.

Dzień ten (...) upamiętnia także przekazanie za pośrednictwem proroka Mojżesza Dziesięciu Przykazań na górze Synaj. Tego dnia czyta się Pismo i powstrzymuje od pracy.

${ }^{1}$ Artykuł zamieszony w „Łuwachłar dert jiłha (5693-5696). Kalendarz karaimski na cztery lata (1.X.1932-16.IX.1936)", wyd. przez A. Mardkowicza w Łucku w roku 5692 (1932), s. 8-9 Skróty pochodzą od redakcji. 
Byrhy kiuniu. Święto Trąb. Święto to wypada na pierwszy dzień miesiąca Ajrychsy-aj (wrzesień-październik). Jest początkiem roku, pierwszym dniem pokuty dniem dziękczynienia.

Od tego dnia rozpoczyna się dziesięciodniowy czas pokuty. Przez te dni w kienesie odprawiane są modlitwy o świcie, podczas których Karaimi oddają się pokucie, przygotowując się na dzień Boszatłych.

Boszatłych kiuniu. Dzień Pojednania. Dzień pokuty i wyrzeczenia się grzechu. Święto jest obchodzone dziesiątego dnia miesiąca Ajrychsy. Cały dzień obowiązuje post. Karaimi spędzają cały ten dzień na modlitwach w kienesie, prosząc przed obliczem Boga i wobec ludzi o wybaczenie swoich złych postępków.

Chydży Ałaczychłarnyn. Święto Namiotów. Trwa osiem dni - zaczyna się o zachodzie słońca 14 dnia miesiąca Ajrychsy, kończy 22 dnia tegoż miesiąca.

Święto to zostało ustanowione na pamiątkę tego, jak Bóg wyprowadziwszy lud Izraela z Egiptu, osiedlił ich w namiotach i chronił od wszelkiego złego przez czterdzieści lat ich wędrówki po pustyni.

Święto to bywa też nazywane Świętem Zbiorów, gdyż w tym czasie w Ziemi Świętej dobiega końca drugi zbiór plonów z pól.

W pierwszy i ósmy dzień wierni oddają się świętej lekturze, nakazane jest powstrzymywanie się od pracy, a pożywienie należy przygotować wcześniej. Podczas sześciu środkowych dni można pracować, jedynie w kienesie modlitwy trwają dłużej.

(...) Ósmego dnia w kienesie czytany jest ostatni fragment Tory i rozpoczyna się nowy cykl jej odczytywania - w następną sobotę czytana jest pierwsza parasza (fragment Pisma Świętego odczytywany co tydzień kolejno przez cały rok - przyp. tłum.) „Na początku”.

Kynysz. To dwudniowe małe święto wypada 14. i 15. dnia miesiąca Siuwiuńcz-aj (luty-marzec). Są to wesołe dni upamiętniające ocalenie ludu Izraela od prześladowań z rąk bezbożnego Hamana (ministra perskiego króla Achaszwerosza, o którym opowiada księga Estery - przyp. tłum.).

\section{Posty}

Post 24. dnia miesiąca Ajrychsy-aj (wrzesień-październik). Post ten zachowuje się dla potwierdzenia zobowiązania (...) przestrzegania przez wszystkie pokolenia tego, co napisano w Piśmie i szanowania słowa Pisma.

Post 10. dnia miesiąca Kysz-aj (grudzień-styczeń) upamiętnia oblężenie Jerozolimy przez wojska Chaldejczyków.

Post 9. dnia miesiąca Jaz-aj (czerwiec-lipiec) został ustanowiony dla upamiętnienia zdobycia Jerozolimy przez Babilończyków i oślepienia Sedecjasza króla Judy.

Post 7. dnia miesiąca Ułah-aj (lipiec-sierpień) jest pamiątką po zniszczeniu świątyni na rozkaz dowódców armii Nabuchodonozora, króla Babilonu. 
Post 10. dnia miesiąca Ułah-aj, zwany inaczej Kurban, upamiętnia spalenie Świątyni i Jerozolimy (...). Tego dnia Karaimi wspominają swoich zmarłych i czytają ku ich czci żałobne modlitwy w kienesie i na cmentarzu.

Jeżeli którykolwiek z tych postów (z wyjątkiem Kurban) wypada w sobotę, post przekłada się na następny dzień, czyli na niedzielę. Jedynie Kurban zaczyna się dzień wcześniej, w piątek, aby nie skracać dni żałoby.

Okres trwający od Postu 9. dnia miesiąca Jaz-aj do postu Kurban nazywa się awuz jabar (zamyka usta). W te dni należy się powstrzymywać od śpiewu i muzyki. Robi się tak na znak żałoby po zniszczeniu Świątyni (...). Przez ostatnie dziesięć dni okresu awuz jabar (od pierwszego dnia miesiąca Ułah-aj do Kurban) nie należy jeść mięsa. Z postem Kurban kończy się awuz jabar i następuje awuz aczar (otwiera usta), co oznacza, ze wtedy można otworzyć usta, by śpiewać, cieszyć się i jeść mięso.

Specjalne soboty

Ułłu szabbat, czyli wielka sobota to ostatnia sobota przed Chydży Tymbyłłarnyn.

Bijancz szabbaty, czyli radosna sobota to pierwsza sobota po poście Kurban. W ten dzień odprawia się radosne nabożeństwo po nabożeństwach żałobnych odprawianych w czasie postu.

Teszuwa szabbaty, czyli pokutna sobota. Wypada podczas dni pokuty między Świętem Trąb a Świętem Pojednania.

Tłumaczyła z j. karaimskiego Anna Sulimowicz 